Museum Movies 



\section{Museum Movies}

The Museum of Modern Art and the Birth of Art Cinema

HAIDEE WASSON

University of California Press

BERKELEY LOS ANGELES LONDON 
University of California Press

Berkeley and Los Angeles, California

University of California Press, Ltd.

London, England

(C) 2005 by The Regents of the University of California

Parts of earlier versions of the following chapters were previously published: Chapter 3 as "The Cinematic Subtext of the Modern Museum: Alfred H. Barr, Film and the Museum of Modern Art," The Moving Image: Journal of the Association of Moving Image Archivists 1, no. I (Spring 2001): 1-28; chapter 4 as "Some Kind of Racket: The Museum of Modern Art, Hollywood and the Problem of Film Art, 1935," Canadian Journal of Film Studies / Revue Canadienne D'Études Cinématographiques 9, no. I (Spring 2000): 5-29; and chapter 5 as "What's Old Is New Again: Film History's New York Debut," Continuum: Journal of Media and Cultural Studies 12, no. 3 (November 1998): 245-66. These chapters are reprinted here by permission.

Library of Congress Cataloging-in-Publication Data

Wasson, Haidee, 1970-

Museum movies : the museum of modern art and the birth of art cinema / Haidee Wasson.

p. $\mathrm{cm}$.

Includes bibliographical references and index.

ISBN 0-520-22777-8 (alk. paper).-ISBN o-520-24131-2 (pbk. : alk. paper)

1. Museum of Modern Art (New York, N.Y.). Film LibraryHistory. 2. Motion pictures-Preservation-United States. 3. Motion pictures-United States-History. I. Title.

$\mathrm{PN}_{1993 \cdot 4 \cdot \mathrm{W}_{27} \quad 2005}$

$026^{\prime} .79143^{\prime} 09471-\mathrm{dc2} 2$ 2004024026

Manufactured in the United States of America
$\begin{array}{llllllllll}14 & 13 & 12 & 11 & 10 & 09 & 08 & 07 & 06 & 05\end{array}$
$\begin{array}{llllllllll}10 & 9 & 8 & 7 & 6 & 5 & 4 & 3 & 2 & 1\end{array}$

The paper used in this publication meets the minimum requirements of ANSI/NISO Z39.48-1992 (R 1997) (Permanence of Paper). 
For Jan and Judy,

my very own dynamic duo 
